\title{
HARMONY OF PROFESSION AND CAREER
}

\section{Tetyana Shterma}

\author{
Private Higher Educational Institutions "Bukovina University", Chernivtsi, \\ Ukraine
}

\section{Svitlana Pelypchuk}
Private Higher Educational Institutions "Bukovina University", Chernivtsi, Ukraine

OMESTE

JEL Category: J24, 015

\begin{abstract}
The world in which we live is constantly evolving and growing. Therefore, the essential thing for long term business success is learning and professional growth of employees. There are plenty of ways for career development of talented people. Each employee is personally responsible for identifying new opportunities and determines his own career path, but definitely, he should receive full support and assistance. The article deals with the aspects of a career building that play an important role in the career development of young professionals. But the result is worth it: the success in the profession is primarily the success of an individual; it is a professional and personal fulfillment. A person discovers and reveals their skills, personal and professional qualities. Moreover, professional activities allow a person to feel their importance to others, to society as a whole and get some compensation from it.
\end{abstract}

Keywords: career, management, professional development, staff, specialist, practical experience, skills, capacity, desired position

\section{INTRODUCTION}

Respect for the individual is especially appreciated. What does this mean in everyday life? We are convinced that employees play a vital role in achieving the goals of the company: promoting the development and growth of customers, investors, and the public. Expectations of business partners can justify truly outstanding professionals who have the opportunity to work on

The address of the corresponding author:

Tetyana Shterma

拝"sht.tatjana@gmail.com interesting projects, receive a high-quality education, gain experience in Ukraine and abroad.

There should be a career scheme that provides the high level of personal and professional maturity and contribution of each employee in achieving mutual success and business development.

The world in which we live is constantly evolving and growing, so essential thing for long term business success is learning and professional growth of employees. There are plenty of ways for career development of talented people. Each employee is personally responsible for identifying 
new opportunities and determining their career path, but it definitely should receive full support and assistance.

Career is a successful promotion in public, service, research and other activities. It is an integral part of the way of life of the person who wants to succeed in life. Career development is all the same methods and actions that people can use to achieve any goals they have set. To organize your career correctly, to foresee all the traps in your way, you need to learn how to allocate your time and energy, how to be able to choose the needed goals and how to set your objectives.

From the organizational point of view, career is viewed as a set of interrelated decisions of an individual about the choice of any variant of the future activity, based on the opportunities that are open to them, overcoming differences between their actual and desired official position. As these decisions are made under conditions of lack of information, subjective evaluation of themselves and circumstances, lack of the time or emotional instability, they are not always consistent, rational, focused, and justified.

A career can be dynamic, associated with changing jobs and static, carried out in one place and at one position through professional growth. It can be vertical, which provides career development and horizontal, which takes place within one level of management but with the change of classes, sometimes professions. Combining these two approaches provides the stepped career. In other words, career success can be seen both in terms of promotion from one position to a higher one and in terms of the degree of mastery of a certain profession, skills, and knowledge that constitute it.

XXI century put the meaning of the word "career" to a new level. Building a career in the modern world is a prerequisite for self-realization in professional activities. It is difficult to imagine a successful and stable company that would not announce promotion opportunities. It is even harder to imagine a professional who would not have dreamed of a position of the head of department, company or holding. In the depths of these aspirations so often used word "careerist" was born. For many people it has a negative connotation, implying an unprincipled person, indifferent to the interests of colleagues and companies. For professionals of staffing market, it is rather a positive characteristic.

\section{PERSONAL DEVELOPMENT}

In today's world, it is important to be not only a good specialist, it is important to be the best one. Therefore, it is advisable to consider the thesis of personal development that does not require evidence. In (50 istyn pro osobystyy rozvytok, 2011), there are shown 50 facts, but here will be presented only a few of them:

1. Acquired knowledge is no guarantee that you will grow and develop, the main thing is the ability to apply them.

2. A good idea without action is nothing.

3. Opportunities don't have to be searched for, they have to be created.

4. $10 \%$ of our lives are affected by uncontrollable circumstances, and the remaining $90 \%$ are affected by how we respond to these circumstances.

5. What we do not start today cannot be completed tomorrow, so you should never delay.

6. Waiting for ideal conditions to carry out your plans, you may be left with nothing.

7. As long as you keep doing what you're doing, you'll keep getting what you get.

8. Do not be afraid of changes. They most often occur at precisely the moment when they are needed.

9. Discipline is needed in order to choose the first out of two possibilities: what you want most of all and what you want right now.

10. The harder the way is; the more success awaits you at the end.

Of course, there are many aspects of promotion, and they play a pivotal role in the career development of young professionals. But the result is worth it: the success in the profession is primarily the success of you as a personality; it is your professional and personal fulfillment. Climbing the ladder of career ladder has never been an easy thing, especially in the present conditions of constant growth of companies. The labor market in Ukraine is gradually approaching the world standards, mastering new laws in the field of employment and personnel management. 
Professional activity is one of the most important areas of personal fulfillment. This is where a person discovers and reveals their skills, personal and professional qualities. Moreover, professional activity allows a person to feel their importance to others, to society as a whole and get some compensation from it. Promotion plays a special role in the professional activity as a process of conscious implementation of "professional or official promotion" that helps a person to receive a certain status, which guarantees professional selfaffirmation. On the one hand, promotion means that a person can realize themselves as a subject of society, on the other hand, it means that their activities are appreciated highly enough by others. So, promotion is a stimulus in the professional development of an employee and in the development of their own potential. Success in promotion largely depends on the efficiency of the first steps in education and professional activity. Considerable importance for future life and professional development is education and a choice of a profession. In the first stage of their personal development, young people often make mistakes. For example, studying a particular profession, some people believe that they will not work in the specialty a single day because it is not prestigious, profitable or futile. In this case, time and money spent on education are lost, and the most important is the thing that there is no further vision of their place and role in the professional sphere. Therefore, regardless of where a young person studies we advise to realize that no knowledge can be unnecessary, and from the third year they have to assess their capabilities together with their knowledge and skills objectively. The professional should be able to make decisions, find their way in a new environment, be able to communicate with different people and adapt to the dynamic life.

\section{ASSESSMENT OF SKILLS}

Consequently, their skills can be assessed by treatment of important components of any activity: information and ability to find it, to analyze, to process and to transmit it (Fig. 1); relationships with people - to socialize, to find individual approach to everyone, to influence, to maintain links, to manage; technology - the degree of possession of professional skills, the ability to eliminate malfunctions, to design and so on.

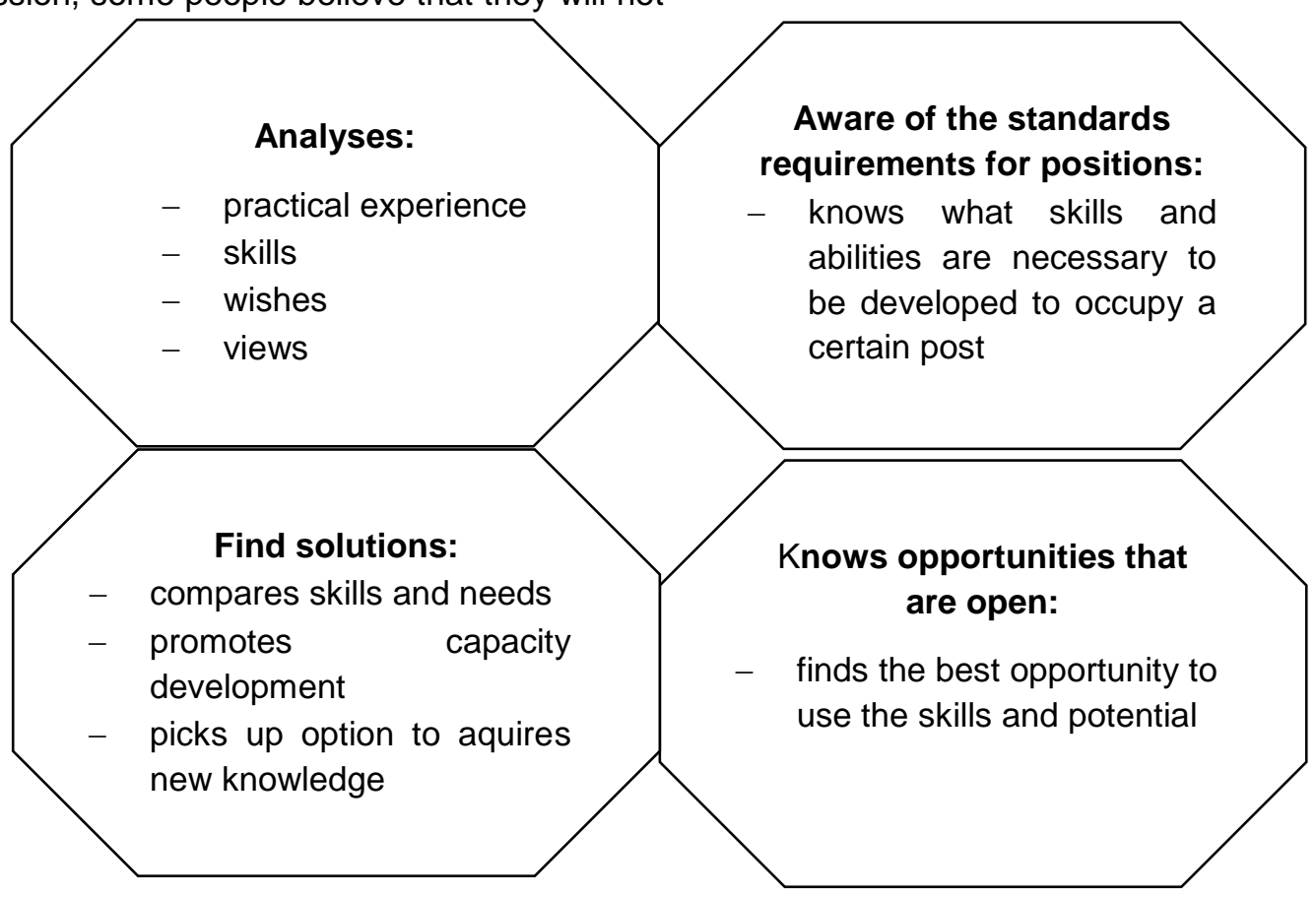

Fig.1. The components of career success

Source: prepared by the author

After such self-examination, it is not difficult to determine what field will need people with their acquisition of knowledge and skills and take steps to the professional and career advancement.
There is a tip to those who are just looking for their first job: "in no way make yourself to work because of a 'prestigious position' and in the 'prestigious company'." The first step is to decide what one see 
himself in 10-15 years, and only then take the first steps in this direction. One should remember the "golden rule": a person makes more than one mistake before reaching a certain result. But, it often happens that the first mistake becomes the last one. Do not accept mistakes as obstacles to professional growth, as any mistake is just a way to change behavior and try to act again but in a different way. For example, if an organization didn't give you a job, try to find a job in their competitors. Knowledge, hard work, communication, targeted actions and justified optimism - these are the building blocks that make up a professional career.

\section{CAREER MANAGEMENT}

There are several factors that influence the development of any type of career orientation. This is a psychological type of personality, cognitive interests, inclinations, professional orientation and professional motivation. Everyone has a set of personal characteristics, concept, motives, values that determine career choice. In a series of career-making solutions of a person, their professional "self-concept" is embodied. Unconscious realization of people's career orientations often happens.

It's hard not to agree that career orientation helps a person to realize themselves professionally. This is possible if the profession is chosen according to their interests and abilities. Otherwise, when the professional choice is determined by a random factor or the circumstances of the situation (proximity of the place of residence, the fashion for this profession, the ability to get a place with the help of an acquaintance, etc.), it is difficult for a person to realize their own professional potential. Professional self-determination and selfactualization of an individual is a long process of development of their relation to the future profession and to themselves as a professional. Success is determined by the activity of the subject of professional activity on the way to their personal development. They choose a profession themselves, they go through the period of professional training themselves and they build actively their own professional career and realize their own personal and intellectual potential (Reznik, 2004). Both development plans are being implemented throughout the life and professional course of a person.

We tend to think that the career achievements of a person depend largely on the level of their personal professional development. There are important aspects such as:

1. the qualification that means the level of preparedness for any type of work;

2. the motivation that includes, both, guides to action and self-motivation, which is directly related to the core values of a person and is not always connected with the realities of the company;

3. the socialization that relates primarily to informal culture of the company (unwritten rules and rituals), which can be a barrier to personal development. There is a risk of negative evaluation by management or colleagues for taking initiative that might endanger the situation of the representatives of the company;

4. an implementation that is directly related to the socialization aspect.

Plans, providing changes, do not meet the proper support. Thus, the company limits the activities of its employees and creates problems for their promotion. A career plan can be defined as a plan of the individual work of the employee that provides personal goal achievement in their field.

There is such a thing as career management. According to E. Meyo, it is a process through which career of individual staff is planned to meet the commercial interests of the organization as well as the benefits and interests of each individual employee. In career management E. Meyo includes:

a. the planning of individual career (professional counseling, workshops on career development planning, employee selfdevelopment plans, identifying career resource);

b. processes of joint career planning (analysis of assessment and level of development, potential assessment centers, development centers, joint career planning);

c. the organizational processes (succession planning, career continuity, advertising of ways of possible development, planning of needs in the workforce, special scheme for 
rapid advancement of the prospective employees) (Koulopoulos, 2008).

Career management processes contribute to the competitiveness of employees and cause the need for joint training of management and employees to cope with the changes they entail. The success of these processes depends largely on the organizational culture: all the managers of the company share with the staff the principles and the value priorities (Kaunt, 2003).

One of the factors of the career development is labor motivation. It is studied by theories focused on the content and theories oriented on the process. The first group of theories examines basic human needs and motivations and motives of a higher order, the existence and development of which, according to A. Maslow, involves selfactualization of an individual. Procedural theories or the theories of achievement motivation study the process of selecting a way of behavior related to the expectations of an individual and subjective assessment of the effects of their actions on the working place. Mechanism of the influence of the specific needs and motives in the formation of a certain behavior is still insufficiently studied. However, it should be noted that the link between the needs, motives, emotions on the one hand and making the goal of self-regulation of labor behavior, on the other hand, is empirically established (Koulopoulos, 2008).

Career planning allows for:

1. Implementation of employee desires in terms of the development of their potential and professional growth.

2. The constant flow of qualified professionals who become a reserve.

3. The most efficient use of the staff now and in the future.

4. Employees' confidence in their own abilities.

5. Creation of a reserve for the promotion within the company.

6. A careful attitude of the company to its employees.

Successful career planning requires the participation of three interested sides:

- the company is responsible for creating the situation that promotes individual growth, learning and training of staff during the work and after work. This allows the employees to acquire the necessary professional skills, get information about the possibilities of promotion in other areas and use these possibilities. Most newly hired employees have to start their career from the lowest positions;

- the leader serves as the catalyst that stimulates implementation of evidence-based planning for the future. In addition, the leader can show the employee the right direction with regards to the needs of the company. The leader also knows the capabilities of their employees and takes into account their aspirations. Finally, the leader is constantly in contact with the staff and informs them of the change in the company's needs and the impact of these changes on professional growth. The leader encourages his workers, evaluates their work properly and provides advice;

- employees play the most important role. They should assess their strengths and weaknesses, and be able to determine how and why they reached the present state. Finally, the employee must determine the next step in his career development, the ways to assess progress and plan the future options.

The following methods have been used in the career planning:

1. Methods of values specification. This method allows determining the most important life and labor interests. Factors such as prestige, the location of the company, diversity, the presence of stress, stimulation of intellectual activity, authorities are examined and classified in terms of their relevance to humans.

2. Methods of defining the level of work satisfaction. This technique is designed to receive information from the employee on several activities that give him pleasure. The employee also answers the questions the purpose of which is to find out why a particular activity gives him pleasure. It aims to determine the type of activity that every specific employee prefers.

3. Personal development and significance of work. This is a series of techniques that a person can use to assess the importance of special elements of work. This takes into account such factors as professional 
development, the emergence of new problems, new opportunities, a sense of belonging to an important cause.

Managers must understand that some employees are absolutely satisfied with their current position and the type of their work. Such employees should never be focused on professional growth and promotion. Simultaneously, the manager must inform them of the additional opportunities that they can be provided.

Not all employees pass classic career stages: preliminary, development, promotion, preservation and maintenance of the achieved, completion and retirement. In career management, there is a concept called "career plateau." Plateau is a point in a career when the probability of further promotion is very small. This is the ending point of a rising career (Drozdov, 2015).

The main characteristics of four categories of employees in the "career plateau":

- "solid people" are high-level employees, whose "career plateau" which has an enviable height, but promotion, most likely, is not expected:

- "frozen" are workers with limited potential for promotion, working with efficiency, lower than expected;

- "stars" are high-level employees with opportunities for promotion, going one by one:

- "aliens" are employees with high potential for promotion, but without formed "plateau".

The key to choosing ways of promotion is to understand that not only factors, and not just a personality influence the promotion but the ways they interact. The leader manager should be able to identify the needs of the employee and the employee should have an idea of their existing and potential opportunities, the ability to express them in the future.

Consequently, career and promotion should be based on the total participation of both sides and their shared responsibility for "their" part of the process. Career determines not only the success or failure, as people consider it. It has an internal attitude and behavior, a gradual change of skills, abilities and professional opportunities associated with the activity.
In its essence career has a strategic character because it is directed to promoting an employee in the future. All people are interested in their career. Any life is in continuous changes, in human adaptation to developments, in improving ways of life, in an effort to achieve a higher status. But for some people this life is the burden of the struggle for physical survival and for others it is a natural process of living arrangement, others are seeking their way of life and realize it by trials and errors and usually with significant losses.

The question of the strategic plan is about how the first place can advance to the second one and the second place to the third one in order the third place would not have losses appears? E. Fromm (Fromm, 1992) gives the following answer - to expand the space of their destiny, to strengthen things that promote life. This can be a basis for understanding the nature of career strategies.

Prof. Romanov V.L. determines that the essence of a career strategy is to provide career so that a way of promotion could provide optimal use of the driving mechanisms and weakened the effect of any factor of deterrence and resistance. This definition of a career strategy implies that its main purpose is to ensure the stability of the career process, rather than setting a specific social or official status in the strategic period. The strategic plan of any person who begins to develop a career should take place in stages so that only close purposes can be determined relatively clearly. It is impossible to predict events that may be on a career path and affect its performance. (Vynohrads'kyy, Vynohrads'ka, \& Shkanova, 2009)

Career strategy is the art to reduce or eliminate the effects of inhibiting factors to achieve incremental goals of the social or official status of a person in the strategic period. Its aim is to ensure the stability of the career process. In the implementation of individual promotion, the following principles are used: continuity, comprehension, speed, agility and efficiency.

Career tactics are the art of the possible implementation of a career strategy.

Career planning is one of the functions of the department of staff organization. The department determines employee's future development and the stages of achieving goals and promotion. When planning a career, the potential 
opportunities and the abilities of the employee are compared to the requirements of the organization, its strategy of development.

People who are dealing with the employee's development plan are the following:

- the employee;

- personnel manager;

- line manager.

They provide measures for planning each individual employee's career.

The employee provides the following measures:

1. initial orientation;

2. the selection of a structural unit and a future position;

3. performing their work at their position;

4. assessment of the prospects for growth and planning it;

5. implementation of measures of growth.

The process of assessment and staff development includes:

1. The implementation of the necessary corporate policies and procedures (definition of objectives, assessment and so on).

2. Each worker:

- is actively involved in planning and assessment of their activities;

- is responsible for the results of their work;

- seeks and captures the most effective ways of providing the greatest contribution to the joint success;

- $\quad$ is responsible for planning their career;

- is actively involved in the assessment to identify which aspects of their personality need development.

"The philosophy of development" is simple: everyone is a master of their career as they get greatest benefits from active management of their activities.

In the management of effectiveness not only quantitative indicators (business growth, financial results) are important, but also the way how employees reach their goal. The task of the employee is that they should rely on global values and characteristics of the behavior of the company in their work. The company has to identify and use effectively staff skills for business development and people have to assess their strengths and weaknesses, identify career goals and improve their skills constantly. An employee initiates the process itself, defines development goals and plans necessary measures.

Monitoring results should be based on the following valuation:

- for each specific task or project;

- interim assessments in mid-year;

- the results of the year work.

At each stage of assessment, an employee meets the manager (the leader); they discuss results of work and future plans (including career prospects) together:

The changes expand the outlook of a person, open new perspectives before them, give opportunities to receive new knowledge. That's why workers should be given opportunities to participate in projects and short-term business trips abroad. As a result, the person receives the maximum benefit: acquires experience to work with other categories of customers, explores the new industry, seizes new way of life, immerses in another culture. Each employee can be sure that the company will find the best opportunity for their promotion.

Thus, career does not determine only successes or failures, it has an internal attitude and behavior, a gradual change of skills, abilities and professional opportunities associated with the activity.

So, professional skills, knowledge, experience, persistence and some element of luck are necessary for promotion.

\section{WORKS CITED}

Admin. (2011, Nov 29). 50 istyn pro osobystyy rozvytok. Retrieved from Samorozvitok Info: http://samorozvytok.info/content/50-istin-pro-osobistiy-rozvitok

Drozdov, I. N. (2015). Osnovnyye stadii kar'yernogo rosta. Retrieved from Drozdov land: http://www.drozdovland.ru/index.php?action=add\&id=745\&add\&rod 
Fromm, E. (1992). The anatomy of human destractiveness. Holt Paperbacks.

Kaunt, D. (2003). Organizuy sebya. SPb: Neva.

Koulopoulos, T. M. (2008). Upravleniye znaniyami. Moscow: Eksmo.

Reznik, S. (2004). Personal'nyy menedzhment. Moscow: INFRA-M.

Vynohrads'kyy, M., Vynohrads'ka, A., \& Shkanova, O. (2009). Pryntsypy upravlinnya i planuvannya kar'yernoyi stratehiyi. In M. Vynohrads'kyy, Upravlinnya personalom - (pp. 266-276). Kyyiv: Tsentr uchbovoyi literatury. Retrieved from http://westudents.com.ua/glavy/47906-104-printsipiupravlnnya-planuvannya-karrno-strateg.html

Received for publication: $\quad 15.03 .2016$

Revision received: $\quad 21.08 .2016$

Accepted for publication: $\quad$ 12.12.2016

\section{How to cite this article?}

Style - APA Sixth Edition:

Shterma, T., \& Pelypchuk, S. (2017, Jan 15). Harmony of profession and career. (Z. Cekerevac, Ed.) MEST Journal, 5(1), 86-93. doi:10.12709/mest.05.05.01.11

Style - Chicago Sixteenth Edition:

Shterma, Tetyana, and Svitlana Pelypchuk. "Harmony of profession and career." Edited by Zoran Cekerevac. MEST Journal (MESTE) 5, no. 1 (Jan 2017): 86-93. doi:10.12709/mest.05.05.01.11

Style - GOST Name Sort:

Shterma Tetyana and Pelypchuk Svitlana Harmony of profession and career [Journal] // MEST Journal / ed. Cekerevac Zoran. - Belgrade - Toronto : MESTE, Jan 15, 2017. - 1 : Vol. 5. - pp. 86-93.

Style - Harvard Anglia:

Shterma, T. \& Pelypchuk, S., 2017. Harmony of profession and career. MEST Journal, 15 Jan, 5(1), pp. 86-93.

Style - ISO 690 Numerical Reference:

Harmony of profession and career. Shterma, Tetyana and Pelypchuk, Svitlana. [ed.] Zoran Cekerevac. 1, Belgrade - Toronto : MESTE, Jan 15, 2017, MEST Journal, Vol. 5, pp. 86-93. 